\title{
Biomass and Production Rates of Fine Roots in Two Mangrove Stands in Southern Thailand
}

\author{
Kyotaro NOGUCHI ${ }^{*}$, Sasitorn POUNGPARN ${ }^{2}$, Suthathip UMNOUYSIN ${ }^{2,3}$, \\ Pipat PATANAPONPAIBOON ${ }^{2}$, Decha DUANGNAMOL ${ }^{4}$, Reiji YONEDA ${ }^{5}$, \\ Hajime UTSUGI ${ }^{6}$, Tamotsu SATO $^{6}$ and Ryuichi TABUCHI ${ }^{6}$ \\ ${ }^{1}$ Tohoku Research Center, Forestry and Forest Products Research Institute, Morioka, Japan \\ 2 Department of Botany, Faculty of Science, Chulalongkorn University, Bangkok, Thailand \\ ${ }^{3}$ Department of Biology, Faculty of Science, Silpakorn University, Nakhon Pathom, Thailand \\ ${ }^{4}$ Andaman Coastal Research Station for Development, Kasetsart University, Ranong, Thailand \\ ${ }^{5}$ Shikoku Research Center, Forestry and Forest Products Research Institute, Kochi, Japan \\ ${ }^{6}$ Forestry and Forest Products Research Institute, Tsukuba, Japan
}

\begin{abstract}
Fine roots are a key component of belowground carbon dynamics in forest ecosystems. However, information on fine root dynamics in mangrove forests is still limited. Therefore, in this study we examined the biomass and production rates of fine roots by using soil coring and an ingrowth core method, respectively, at soil depths of $0 \mathrm{~cm}-40 \mathrm{~cm}$ in Avicennia alba and Rhizophora apiculata stands in Ranong Province, southern Thailand. In these stands, the fine root biomass was ca. $3.4 \mathrm{~kg} \mathrm{~m}^{-2}$ and $1.4 \mathrm{~kg} \mathrm{~m}^{-2}$, respectively, while fine root production rates were ca. $450 \mathrm{~g} \mathrm{~m}^{-2}$ year $^{-1}$ and $740 \mathrm{~g} \mathrm{~m}^{-2}$ year $^{-1}$, respectively. Fine root biomass was not significantly different between the surface $(0 \mathrm{~cm}$ $20 \mathrm{~cm})$ and subsurface $(20 \mathrm{~cm}-40 \mathrm{~cm})$ soil in both stands. The fine root production rate was also similar between the soil layers in the R. apiculata stand, whereas it decreased with soil depth in the $A$. alba stand. The patterns of vertical distribution of fine root production rates probably reflected the species characteristics of $A$. alba and $R$. apiculata, and suggested that fine root production in the subsurface soil contributes significantly to belowground carbon dynamics, especially in $R$. apiculata.
\end{abstract}

\section{Discipline: Forestry}

Additional key words: Avicennia alba, ingrowth core, Rhizophora apiculata, soil depth, vertical distribution

\section{Introduction}

Tree roots less than $2 \mathrm{~mm}$ in diameter are traditionally defined as 'fine' (Noguchi et al. 2007, Finér et al. 2011). Fine roots are located in the most distal parts of root systems and play a key role in the uptake of water and nutrients from the soil (Volder et al. 2005, Rewald et al. 2011). Moreover, fine roots have been suggested to be a major pathway of belowground carbon flux, although their biomass usually accounts for $<10 \%$ of tree biomass (Makkonen \& Helmisaari 1998, Brunner \& Godbold 2007). This is mainly due to high turnover rates or short life spans of the fine roots, ranging from less than a month to several years (Wells \& Eissenstat 2001, Strand et al. 2008, Brunner et al. 2013). As a result, fine root production rates often account for $30 \%-40 \%$ of net primary productivity in forest ecosystems, and in excess of 50\% in some cases (Hendrick \& Pregitzer 1993, Tateno et al. 2004). Therefore, to deepen our understanding of carbon dynamics in forest ecosystems, we need to improve our knowledge of the fine root dynamics of forest trees.

Mangrove forests are located along coastlines in tropical and subtropical regions. Although covering much smaller areas than inland forests, mangrove forests perform various ecologically important functions such as the stabilization of shorelines and the provision of habitat for aquatic organisms (Srikanth et al. 2016). Mangrove forests are also commercially important for local people in supplying wood for fuel or providing fishing areas. As for carbon dynamics, Donato et al. (2011) suggested that mangrove forests accumulate huge amounts of carbon 
belowground as compared with other forest ecosystems. Roots are considered a major source of the soil organic carbon, although a quantitative study of roots is still difficult in wetlands such as mangrove forests (Alongi 2012). However, Fujimoto (2004) showed that the carbon sequestration capacity varied with forest types, and suggested that Rhizophora forests had greater carbon stocks than other types of mangrove forests. Therefore, studying roots in different forest types would help to improve our knowledge about carbon dynamics in the mangrove forest ecosystem.

Mangrove forests usually have large root systems. In one study, the aboveground to root biomass ratios (T/R) were between 2.0 and 3.0, which is less than those of upland forests (4.0-4.5) (Komiyama et al. 2008). However, information on fine mangrove roots is still limited, although several recent studies have reported fine root production rates in Florida, USA (Castañeda-Moya et al. 2011), Yucatan, Mexico (Adame et al. 2014), Micronesia (Cormier et al. 2015), eastern Thailand (Poungparn et al. 2016), and on Hainan Island, China (Xiong et al. 2017). These papers showed that annual fine root production rates varied greatly, ranging from ca. $50 \mathrm{~g} \mathrm{~m}^{-2} \mathrm{y}^{-1}$ to 2,800 $\mathrm{g} \mathrm{m}^{-2} \mathrm{y}^{-1}$. The reported fine root biomass in mangrove forests also varied greatly, ranging from $0.075 \mathrm{~kg} \mathrm{~m}^{-2}$ to $21.45 \mathrm{~kg} \mathrm{~m}^{-2}$ (Cormier et al. 2015). These large variations could be due to differences in such factors as the tree species, stand structure, environmental conditions, and soil depths examined. It is thus necessary to collect more data and examine it in relation to abiotic or biotic factors, in order to better understand fine root dynamics in mangrove forests. Therefore, the objectives of the present study were to estimate the biomass and production rates of fine roots in Avicennia alba and Rhizophora apiculata stands in southern Thailand. Avicennia species are known to have cable roots that spread out horizontally in the surface soil, whereas Rhizophora species have relatively deep root systems (Gill \& Tomlinson 1977, Tabuchi et al. 1983, Tabuchi 1995, Dahdouh-Guebas et al. 2004). In this study, we thus focused on changes in the fine root biomass and production rates by soil depths.

\section{Materials and methods}

\section{Study site}

This study was conducted in two mangrove stands at the Andaman Coastal Research Station for Development of Kasetsart University in Ranong Province, southern Thailand $\left(9^{\circ} 22^{\prime} \mathrm{N}, 98^{\circ} 23^{\prime} \mathrm{E}\right)$ (Fig. 1). We established $30 \mathrm{~m}$ $\times 50 \mathrm{~m}$ and $10 \mathrm{~m} \times 30 \mathrm{~m}$ plots in an Avicennia alba stand and a Rhizophora apiculata stand, respectively, which were in the same stands of plot A (A. alba) and plot C
(R. apiculata) shown in Hirata et al. (2010). The study region has semidiurnal tide. In this region, $A$ alba communities are usually found in areas such as riverbanks that have a long inundation period, whereas $R$. apiculata communities are located on slightly higher ground levels (Fujimoto et al. 1999, Mochida et al. 1999, Chalermchatwilai et al. 2011). However, at our study site, the distance from the adjacent river was longer for the $A$. alba stand than for the R. apiculata stand (Fig. 1). Table 1 lists the stand characteristics of this study. The stand density and mean stem diameter at breast height of the $A$. alba trees were 390 trees ha ${ }^{-1}$ and $20.4 \mathrm{~cm}$, respectively,

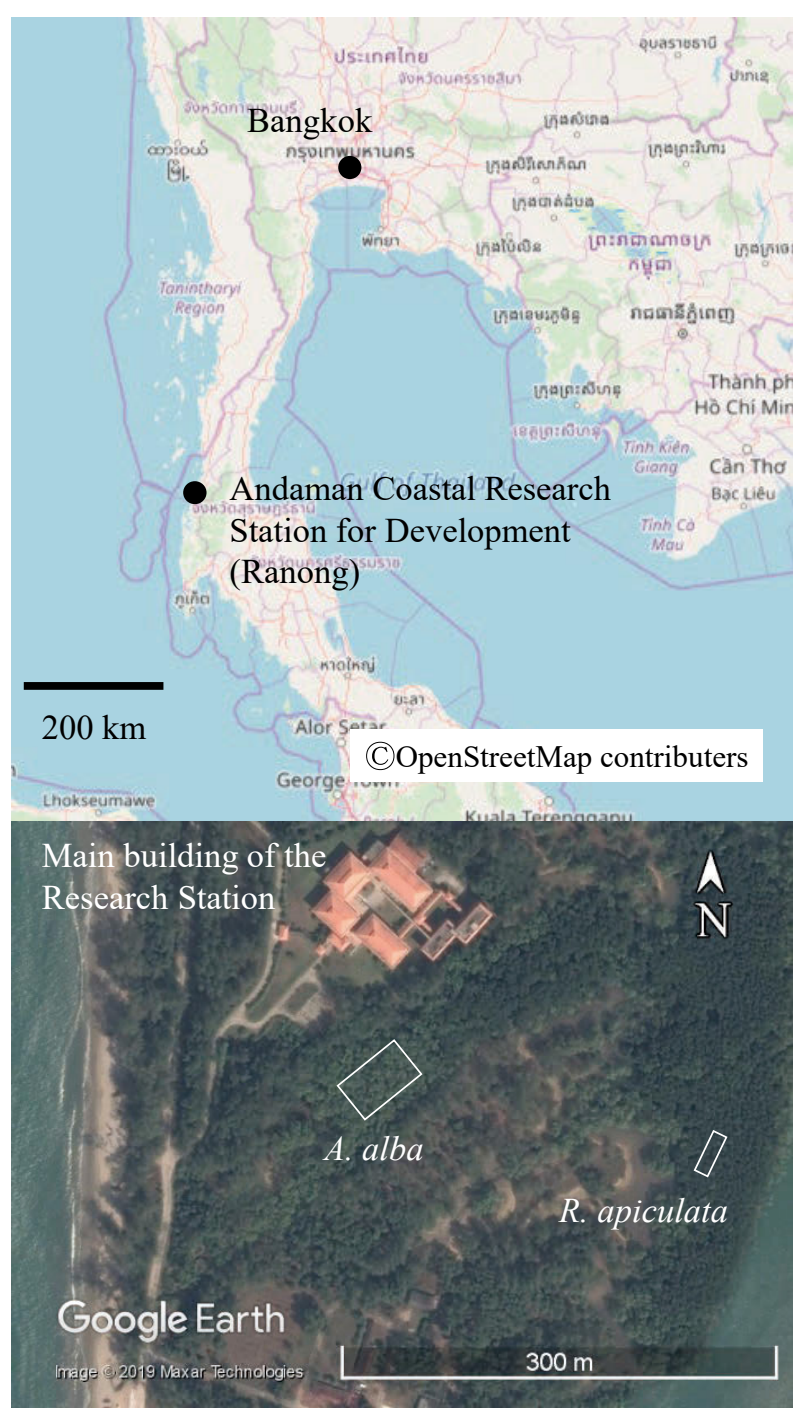

Fig. 1. Location of the study site

Top: Location of the Andaman Coastal Research Station for Development of Kasetsart University (Ranong). Bottom: Locations of the Avicennia alba plot and the Rhizophora apiculata plot. The image data: Top, OpenStreetMap contributors (https://www. openstreetmap.org/copyright); Bottom, Google, Maxar Technologies, added with plot information. 
whereas the stand density and mean stem diameter at 0.3 $\mathrm{m}$ above the highest stilt roots of the $R$. apiculata trees were 2,500 trees $\mathrm{ha}^{-1}$ and $11.4 \mathrm{~cm}$, respectively. The mean annual temperature and annual precipitation in the 20102014 period were $27.7^{\circ} \mathrm{C}$ and $4,470 \mathrm{~mm}$, respectively. Soil temperature was recorded for one year from December 2012 using temperature recorders (Thermochron SL, KN Laboratories, Osaka, Japan) installed at a soil depth of 10 $\mathrm{cm}$. The mean soil temperature at a depth of $10 \mathrm{~cm}$ was $28.1^{\circ} \mathrm{C}$ and $27.6^{\circ} \mathrm{C}$ in the $A$. alba and $R$. apiculata stands, respectively. The temperature ranged from ca. $25^{\circ} \mathrm{C}$ to $30^{\circ} \mathrm{C}$ in both stands and fluctuated over intervals of about two weeks. Soil carbon and nitrogen concentrations were determined by the Walkley-Black method with soil samples $(\mathrm{N}=6)$ collected by soil coring using plastic tubes $2.14 \mathrm{~cm}$ in diameter and $100 \mathrm{~cm}$ in length. The carbon and nitrogen concentrations in the soil $(0 \mathrm{~cm}-100$ cm depth) were $4.2 \mathrm{~g} \mathrm{~kg}^{-1}$ and $0.83 \mathrm{~g} \mathrm{~kg}^{-1}$, respectively, in the A. alba stand, and $19.8 \mathrm{~g} \mathrm{~kg}^{-1}$ and $0.95 \mathrm{~g} \mathrm{~kg}^{-1}$, respectively, in the $R$. apiculata stand. These stands were impacted by the huge tsunami of the Indian Ocean earthquake in December 2004 (Matsumoto et al. 2006, Hirata et al. 2010). The thickness of sand deposits delivered by the tsunami was $5 \mathrm{~cm}-10 \mathrm{~cm}$ and about 20 $\mathrm{cm}$ in the $A$. alba and $R$. apiculata stands, respectively (Tabuchi, personal observation), where stand density decreased by $20 \%$ and $15 \%$, respectively, one year after the tsunami. However, most of the dead trees were relatively small, with negligible changes in aboveground biomass (data not shown). After 2005, the increment of aboveground biomass recovered and was $210 \mathrm{~g} \mathrm{~m}^{-2} \mathrm{y}^{-1}$ and $870 \mathrm{~g} \mathrm{~m}^{-2} \mathrm{y}^{-1}$ in $A$. alba and R. apiculata stands, respectively, in 2010-2012 (Table 1).

\section{Fine root biomass and production}

In this study, fine root production rates were estimated by using an ingrowth core method. In December 2012, two and three 10-m parallel lines were set ca. $1 \mathrm{~m}-2 \mathrm{~m}$ apart in the $A$. alba and $R$. apiculata stands, respectively (Fig. 2). Then, 10 and 14 ingrowth cores were installed along these lines in the A. alba and $R$. apiculata stands, respectively, at a spacing of ca. $1 \mathrm{~m}$ $2 \mathrm{~m}$. These ingrowth cores $(3.2 \mathrm{~cm}$ in diameter and $40 \mathrm{~cm}$ in length) were prepared using a 2-mm plastic mesh. The cores were inserted vertically into the soil and filled with root-free sand obtained from the beach adjacent to the study plots. In December 2013, those ingrowth cores were sampled: soil cores containing the ingrowth cores were dug up using a metal tube $10 \mathrm{~cm}$ in diameter, and then the soil outside of the ingrowth cores was carefully removed using knives and scissors to avoid any loss of roots. We collected six and ten ingrowth cores from the $A$. alba and $R$. apiculata plots, respectively. Fine root biomass was estimated by soil coring. In December 2014, five soil cores $40 \mathrm{~cm}$ in length were collected from each of the plots using a metal tube $3.2 \mathrm{~cm}$ in diameter. Both the ingrowth core and soil core samples were divided into two parts according to soil depth: $0 \mathrm{~cm}-20 \mathrm{~cm}$ and $20 \mathrm{~cm}$ $40 \mathrm{~cm}$. The obtained samples were rinsed in tap water on a sieve with $0.5 \mathrm{~mm}-\mathrm{mm}$ openings, and fine roots $<2 \mathrm{~mm}$ in diameter were picked up manually with tweezers. Roots $2 \mathrm{~mm}-5 \mathrm{~mm}$ in diameter were also collected from the ingrowth core samples. In this study, we did not distinguish live roots from dead ones for the ingrowth core samples. For the soil core samples, however, we collected only resilient and firm roots as alive roots. The fine root samples were then dried at $80^{\circ} \mathrm{C}$ for three days and weighed.

Table 1. Characteristics of the Avicennia alba and Rhizophora apiculata stands

\begin{tabular}{|c|c|c|}
\hline Dominant species & Avicennia alba & Rhizophora apiculata \\
\hline Stand density ${ }^{\mathrm{a}}\left(\right.$ trees $\mathrm{ha}^{-1}$ ) & 390 & 2,500 \\
\hline Mean stem diameter ${ }^{\mathrm{a}}(\mathrm{cm})$ & 20.4 & 11.4 \\
\hline Basal area $\left(\mathrm{m}^{2} \mathrm{ha}^{-1}\right)$ & 14.3 & 30.0 \\
\hline Aboveground biomass ${ }^{\mathrm{a}}\left(\mathrm{AGB}, \mathrm{kg} \mathrm{m}^{-2}\right.$ ) & 10.5 & 21.7 \\
\hline AGB increment ${ }^{\mathrm{b}}\left(\mathrm{g} \mathrm{m}^{-2} \mathrm{y}^{-1}\right)$ & 210 & 870 \\
\hline Leaf litter production ${ }^{\mathrm{c}}\left(\mathrm{g} \mathrm{m}^{-2} \mathrm{y}^{-1}\right)$ & $750 \pm 36$ & $776 \pm 35$ \\
\hline Soil organic carbon ${ }^{\mathrm{d}}\left(\mathrm{C}, \mathrm{g} \mathrm{kg}^{-1}\right)$ & $4.2 \pm 0.7$ & $19.8 \pm 2.9$ \\
\hline Soil nitrogen $\left(\mathrm{N}, \mathrm{g} \mathrm{kg}^{-1}\right)$ & $0.83 \pm 0.21$ & $0.95 \pm 0.08$ \\
\hline
\end{tabular}

a) Data from 2012, calculated from stem diameter using allometric equations (Komiyama et al. 1988)

b) Data from 2010-2012

c) Data from June 2007-May 2010 (sampled with $0.145 \mathrm{~m}^{2}$ litter traps; mean $\pm \mathrm{SE}, \mathrm{N}=5$ )

d) Data for soil depths of $0 \mathrm{~cm}-100 \mathrm{~cm}$ (determined by Walkley-Black method; mean $\pm \mathrm{SE}, \mathrm{N}=6$ )

e) Data for soil depths of $0 \mathrm{~cm}-100 \mathrm{~cm}$ (determined by micro-Kjeldahl method; mean $\pm \mathrm{SE}, \mathrm{N}=6$ ) 

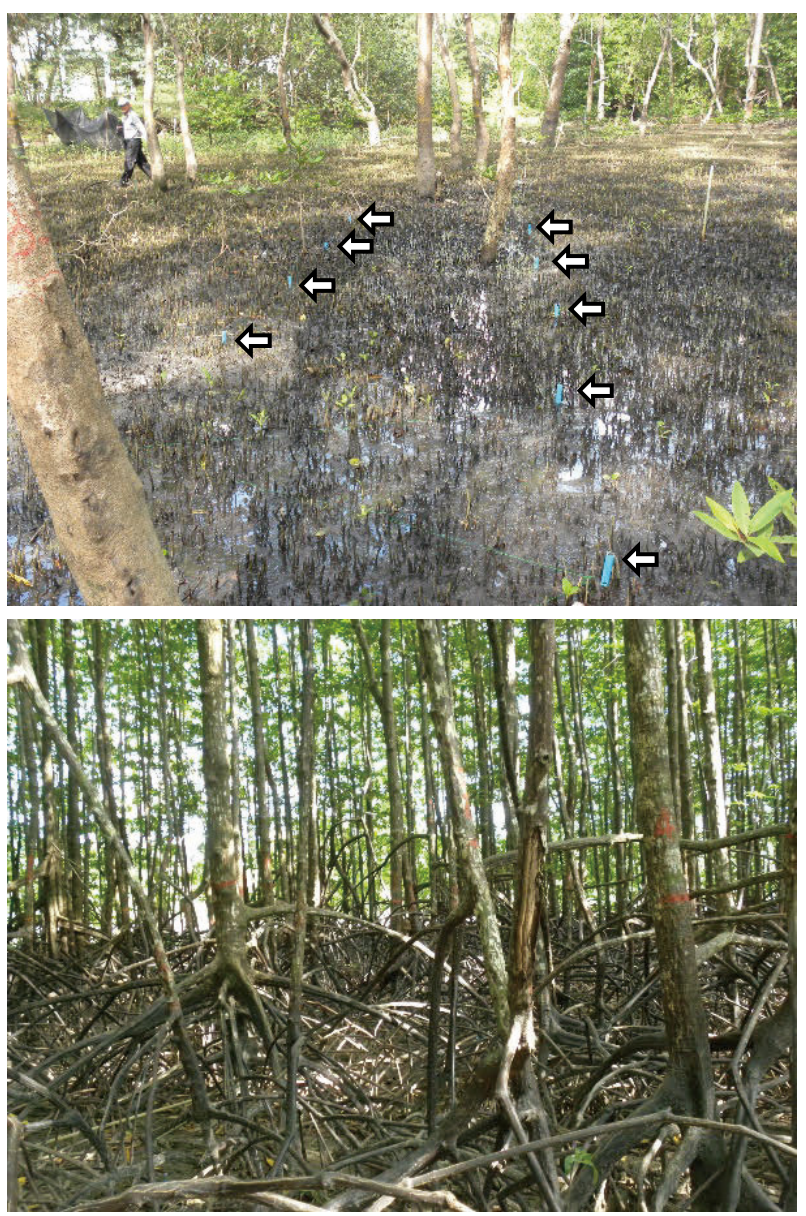

Fig. 2. Photographs of the sampling locations

Top: Avicennia alba plot. Ingrowth cores were installed near the blue poles shown in the photograph (white arrows).

Bottom: Rhizophora apiculata plot.

The photograph was taken above the lines where ingrowth cores were installed.

\section{Statistics}

Two-way analysis of variance (ANOVA) was conducted to examine the effects of soil depth and stand type on fine root biomass and production rates. Sampling locations in each stand were considered as a random effect. Differences were considered significant at $P<$ 0.05. Analyses were conducted using the statistics software JMP 12 (SAS Institute, Cary, NC, USA).

\section{Results}

\section{Fine root biomass and production}

The mean fine root biomass at soil depths of $0 \mathrm{~cm}$ $40 \mathrm{~cm}$ was $3.4 \mathrm{~kg} \mathrm{~m}^{-2}$ and $1.4 \mathrm{~kg} \mathrm{~m}^{-2}$ in the $A$. alba and $R$. apiculata stands, respectively (Table 2 ). The fine root biomass was significantly different between the A. alba and $R$. apiculata stands, whereas the effects of soil depth and the interactive effects of soil depth and stand type on fine root biomass were not significant (Table 3 ). The mean fine root production rates (roots $<2 \mathrm{~mm}$ in diameter) were $450 \mathrm{~g} \mathrm{~m}^{-2} \mathrm{y}^{-1}$ and $740 \mathrm{~g} \mathrm{~m}^{-2} \mathrm{y}^{-1}$ in the $A$. alba and $R$. apiculata stands, respectively (Table 2). Twoway ANOVA indicated that the fine root production rates were significantly different between the stands (Table 3). Although the effects of soil depth on fine root production rates were not significant, the interactive effects of soil depth and stand type were significant. This indicates that the patterns of vertical distribution of fine root productivity were different between the $A$. alba and $R$. apiculata stands. Meanwhile, the production rates of roots $2 \mathrm{~mm}-5 \mathrm{~mm}$ in diameter were ca. $20 \mathrm{~g} \mathrm{~m}^{-2} \mathrm{y}^{-1}$ and 80 $\mathrm{g} \mathrm{m}^{-2} \mathrm{y}^{-1}$ in the A. alba and R. apiculata stands, respectively, which is $5 \%$ and $10 \%$, respectively, of the fine root production rates (Table 2). The fine root turnover

Table 2. Fine root biomass, production, and turnover in the Avicennia alba and Rhizophora apiculata stands

\begin{tabular}{cccccc}
\hline \hline Stand & $\begin{array}{c}\text { Soil depth } \\
(\mathrm{cm})\end{array}$ & $\begin{array}{c}\text { Fine root biomass } \\
\left(\mathrm{kg} \mathrm{m}^{-2}\right)\end{array}$ & $\begin{array}{c}\text { Fine root production } \\
\left(\mathrm{g} \mathrm{m}^{-2} \text { year }^{-1}\right)\end{array}$ & $\begin{array}{c}\text { Small root }_{\text {production }^{2}} \\
\left(\mathrm{~g} \mathrm{~m}^{-2} \text { year }^{-1}\right)\end{array}$ & $\begin{array}{c}\text { Fine root turnover }^{1,3} \\
\left(\text { year }^{-1}\right)\end{array}$ \\
\hline Avicennia & $0-20$ & $1.80 \pm 0.31$ & $333 \pm 88$ & $15 \pm 13$ & 0.18 \\
& $20-40$ & $1.58 \pm 0.31$ & $118 \pm 17$ & $6 \pm 6$ & 0.07 \\
& Total $(0-40)$ & $3.38 \pm 0.43$ & $451 \pm 98$ & $21 \pm 14$ & 0.13 \\
Rhizophora & $0-20$ & $0.55 \pm 0.14$ & $343 \pm 48$ & $24 \pm 12$ & 0.63 \\
& $20-40$ & $0.88 \pm 0.21$ & $393 \pm 34$ & $58 \pm 34$ & 0.45 \\
& Total $(0-40)$ & $1.42 \pm 0.34$ & $736 \pm 62$ & $82 \pm 33$ & 0.52 \\
\hline
\end{tabular}

Data shown are mean $\pm \mathrm{SE}$ (Fine root biomass, $\mathrm{N}=5$; Fine root production, $\mathrm{N}=6$ for $\mathrm{A}$. alba and $\mathrm{N}=10$ for $R$. apiculata).

${ }^{1}$ Data on roots $<2 \mathrm{~mm}$ in diameter

${ }^{2}$ Data on roots $2 \mathrm{~mm}-5 \mathrm{~mm}$ in diameter

${ }^{3}$ Fine root turnover $=$ Mean fine root production rate $/$ Mean fine root biomass 
rate was calculated by the ratio of mean fine root production rate to fine root biomass (Gill \& Jackson 2000). It was 0.18 and $0.07 \mathrm{y}^{-1}$ at the soil depths of $0 \mathrm{~cm}$ $20 \mathrm{~cm}$ and $20 \mathrm{~cm}-40 \mathrm{~cm}$, respectively, in the $A$. alba stand, and 0.63 and $0.45 \mathrm{y}^{-1}$, respectively, in the $R$. apiculata stand (Table 2).

\section{Discussion}

Fine root biomass reported for mangrove forests has varied greatly. However, the data were obtained from different sampling depths and species, which might affect the estimates significantly. As for data obtained by soil coring, the reported fine root biomass (sampling depth; species (genus); Table S1) was $0.075-0.137 \mathrm{~kg} \mathrm{~m}^{-2}(0 \mathrm{~cm}-$ $30 \mathrm{~cm}$; Avicennia-Sonneratia, Rhizophora, Xylocarpus) in eastern Thailand (Chalermchatwilai et al. 2011), 0.54$0.78 \mathrm{~kg} \mathrm{~m}^{-2}(0 \mathrm{~cm}-30 \mathrm{~cm}$; Bruguiera, Rhizophora, Sonneratia) in Micronesia (Gleason \& Ewel 2002), 0.15$0.58 \mathrm{~kg} \mathrm{~m}^{-2}(0 \mathrm{~cm}-45 \mathrm{~cm}$; Bruguiera, Rhizophora, Sonneratia etc.) in Micronesia (Cormier et al. 2015), $0.32-0.66 \mathrm{~kg} \mathrm{~m}^{-2}(0 \mathrm{~cm}-90 \mathrm{~cm}$; Rhizophora, Laguncularia, Avicennia, Conocurpus) in Florida (Castañeda-Moya et al. 2011), $0.14-0.67 \mathrm{~kg} \mathrm{~m}^{-2}(0 \mathrm{~cm}-100 \mathrm{~cm}$; Rhizophora $)$ in southern Thailand (Tabuchi 1995), 0.8-1.1 kg m${ }^{-2}(0 \mathrm{~cm}-$ $100 \mathrm{~cm}$; Rhizophora, Ceriops) in tropical Australia (Robertson \& Alongi 2016), and 0.24-1.9 kg m${ }^{-2}(0 \mathrm{~cm}-$ $100 \mathrm{~cm}$; Ceriops, Bruguiera, Rhizophora, Avicennia) in Hainan Island (Xiong et al. 2017). In other studies with soil block samplings, the reported fine root biomass was $22 \mathrm{~kg} \mathrm{~m}^{-2}(0 \mathrm{~cm}-100 \mathrm{~cm}$ along a $0.2 \times 15.5 \mathrm{~m}$ trench; Rhizophora) in southern Thailand (Komiyama et al. 1987) and 0.49-0.66 kg m${ }^{-2}(0 \mathrm{~cm}-100 \mathrm{~cm}$; Bruguiera, Rhizophora, Sonneratia) in eastern Indonesia (Komiyama et al. 1988). Considering these published data, the fine root biomass in our $A$. alba and $R$. apiculata stands (3.4 $\mathrm{kg} \mathrm{m}^{-2}$ and $1.4 \mathrm{~kg} \mathrm{~m}^{-2}$, respectively; Table 2) was likely to be at the highest end of the range for mangrove forests, although a previous study reported exceptionally large

Table 3. Results of two-way ANOVA for examining effects of the stand, soil depth, and interactions between both on fine root biomass and fine root production rates in the Avicennia alba and Rhizophora apiculata stands

\begin{tabular}{lcccc}
\hline \hline & \multicolumn{2}{c}{ Fine root biomass } & \multicolumn{2}{c}{ Fine root production } \\
\hline & $F$-value & $P$-value & $F$-value & $P$-value \\
Stand & $\mathbf{1 2 . 8}$ & $\mathbf{0 . 0 0 7}$ & $\mathbf{6 . 7 9}$ & $\mathbf{0 . 0 2 1}$ \\
Soil depth & 0.06 & 0.813 & 3.02 & 0.104 \\
Stand $\times$ Soil depth & 1.49 & 0.256 & $\mathbf{7 . 7 9}$ & $\mathbf{0 . 0 1 4}$ \\
\hline
\end{tabular}

Bold numbers indicate statistical significance. fine root biomass as mentioned above $\left(22 \mathrm{~kg} \mathrm{~m}^{-2}\right.$; Komiyama et al. 1987). However, we must carefully consider the comparisons as the methods varied among the studies, particularly regarding the criteria of live/dead root separation (e.g., firmness vs. density; Table S1).

Fine root production rates reported for mangrove forests have also varied greatly, possibly due to differences in sampling depth, species, and methods. The fine root production rates (sampling depth; species (genus)) estimated by the ingrowth core method were 46$119 \mathrm{~g} \mathrm{~m}^{-2} \mathrm{y}^{-1}(0 \mathrm{~cm}-45 \mathrm{~cm}$; Bruguiera, Rhizophora, Sonneratia etc.) in Micronesia (Cormier et al. 2015) and $130-210 \mathrm{~g} \mathrm{~m}^{-2} \mathrm{y}^{-1}(0 \mathrm{~cm}-90 \mathrm{~cm}$; Rhizophora, Laguncularia, Avicennia, Conocurpus) in Florida (Castañeda-Moya et al. 2011), which were likely to be lower than the estimates in our A. alba and R. apiculata stands $\left(451 \mathrm{~g} \mathrm{~m}^{-2} \mathrm{y}^{-1}\right.$ and $736 \mathrm{~g} \mathrm{~m}^{-2} \mathrm{y}^{-1}$, respectively; Tables 2 and S2). However, the fine root production rates estimated at shallower soil depths were 44-417 $\mathrm{g} \mathrm{m}^{-2} \mathrm{y}^{-1}(0 \mathrm{~cm}-15 \mathrm{~cm}$; Bruguiera, Rhizophora, Sonneratia) in Micronesia (Gleason and Ewel 2002), $136-233 \mathrm{~g} \mathrm{~m}^{-2} \mathrm{y}^{-1}(0 \mathrm{~cm}-30 \mathrm{~cm}$; Rhizophora, Avicennia) in Honduras (Cahoon et al. 2003), and 332$1340 \mathrm{~g} \mathrm{~m}^{-2} \mathrm{y}^{-1}(0 \mathrm{~cm}-30 \mathrm{~cm}$; Avicennia-Sonneratia, Rhizophora, Xylocarpus) in eastern Thailand (Poungparn et al. 2016), which seem to be comparable to or higher than our estimates at soil depths of $0 \mathrm{~cm}-40 \mathrm{~cm}$ (Tables 2 and S2). It should be noted that the study by Poungparn et al. (2016) was conducted in mangrove stands with similar species compositions (Avicennia alba/Sonneratia caseolaris and Rhizophora apiculata), and that our estimates were within the range shown in their study. Recent studies have suggested that the ingrowth core method might underestimate fine root production rates due to being unable to detect the production of roots that died and disappeared (decomposed) during the incubation period (Osawa \& Aizawa 2012). Therefore, further study would be needed to include the amounts of mortality and decomposition of fine roots during a measurement period for a better estimation of fine root production rates.

In this study, fine-root biomass and production rates were significantly different between the $A$. alba and $R$. apiculata stands (Tables 2 and 3). However, as both stands also varied in stand density (390 vs. 2,500 trees $\mathrm{ha}^{-1}$ ) and aboveground biomass (10.5 vs. $21.7 \mathrm{~kg} \mathrm{~m}^{-2}$ ) (Table 1), we additionally examined the fine root parameters for individual trees. As a result, the calculated mean fine root biomass per tree was greater in the A. alba stand than in the R. apiculata stand ( $86.7 \mathrm{vs.} 5.7 \mathrm{~kg}$ tree $\left.^{-1}\right)$ at our study site. The ratio of fine root biomass to aboveground biomass, however, was 0.322 and $0.065 \mathrm{~kg}$ $\mathrm{kg}^{-1}$ in the $A$. alba and $R$. apiculata stands, respectively. These results suggest that the fine root biomass of 
individual trees was greater in the $A$. alba stand than in the $R$. apiculata stand, due to the greater size of individual trees (aboveground biomass, 269 vs. $87 \mathrm{~kg}$ tree ${ }^{-1}$ ) and larger biomass allocation to fine roots in the $A$. alba stand. The fine root production rate was twice as large as the aboveground biomass (AGB) increment and $60 \%$ of the leaf litter production (LLP) rate in the A. alba stand, while it was $85 \%$ and $95 \%$ of the AGB increment and LLP rate, respectively, in the $R$. apiculata stand (Tables 1 and 2). This suggests that the patterns of assimilate allocation may be different between both stands. To confirm this possibility, the estimates of fine root production rates must be improved by considering the mortality and decomposition of fine roots newly produced in a measurement period, as mentioned above.

There were also differences in the vertical distribution patterns of fine root production rates between both stands (Tables 2 and 3). The fine root production rate was larger in surface soil than in subsurface soil in the $A$. alba stand, but showed a constant distribution in the $R$. apiculata stand between soil depths of $0 \mathrm{~cm}-20 \mathrm{~cm}$ and $20 \mathrm{~cm}-40 \mathrm{~cm}$ (Tables 2 and 3). A decrease in fine root production rates with soil depth was often observed in terrestrial forest ecosystems, which was explained by vertical changes in the physical or chemical properties of the soil (e.g., increasing bulk density, decreasing mineral nutrients; Persson 1980, Hendrick \& Pregitzer 1996, Konôpka et al. 2006). The vertical patterns of fine root production rates could be attributed to species characteristics; Avicennia species are known to have cable roots that spread out horizontally in the surface soil, whereas Rhizophora species have relatively deep root systems (Gill \& Tomlinson 1977, Tabuchi et al. 1983, Tabuchi 1995, Dahdouh-Guebas et al. 2004). As for the $R$. apiculata stand, the negligible vertical changes might also be a result of moderate changes in soil conditions across the examined soil depths $(0 \mathrm{~cm}-40 \mathrm{~cm})$. In some $R$. apiculata stands in southern Thailand, fine root biomass was examined to a soil depth of $100 \mathrm{~cm}$ (Tabuchi 1995). In his study, fine root biomass at soil depths of $0 \mathrm{~cm}-40$ $\mathrm{cm}$ was $44 \%-78 \%$ in natural stands and $40 \%-56 \%$ in plantations (Tabuchi 1995). Considering those results, future studies would need to investigate fine root dynamics in deeper soil layers, especially in the $R$. apiculata stand. Information on fine roots in deeper soil is also important for a better understanding of soil carbon dynamics in mangrove forests, where huge amounts of organic carbon are accumulated, especially at soil depths below $30 \mathrm{~cm}$ (Donato et al. 2011). It should also be noted that in a mangrove forest on Pohnpei Island, radiocarbon dating detected 'modern' carbon in the soil at a depth of $90 \mathrm{~cm}$, which suggests that roots growing into the deep soil layer could be a major source of soil organic carbon (Ono et al. 2015).

In this study, the average rate of fine root turnover across the two stands was 0.33 year $^{-1}$. The results in Table 2 also suggest a higher fine root turnover rate in the $R$. apiculata stand than in the $A$. alba stand. The variations between both stands might reflect the effects of different environmental conditions, such as inundation periods and sediment characteristics. And if we focus on the physiological traits of the two species, the mechanisms used to cope with saline conditions may offer an explanation, although we lack direct evidence. In a recent review on salt tolerance mechanisms in mangrove trees, Parida and Jha (2010) showed that Avicennia species had salt secretion mechanisms, although Rhizophora species did not. Therefore, the $R$. apiculata trees might have a higher fine root turnover rate than the $A$. alba trees in order to reduce salinity stress. However, further study is needed to discuss whether the variation of fine root turnover rate between $A$. alba and $R$. apiculata trees could be explained by their responses to salinity stress.

In conclusion, the present study showed that the $A$. alba and $R$. apiculata stands in Ranong Province, southern Thailand had relatively large fine root biomass with constant vertical distribution at soil depths of $0 \mathrm{~cm}$ $40 \mathrm{~cm}$. Fine root production rates in these stands were comparable to those shown by other published data. In addition, the vertical distribution patterns of fine root production rates suggested that fine roots in subsurface soil would make a significant contribution to belowground carbon dynamics in the $R$. apiculata stand. Fine root turnover rates and patterns of assimilate allocations were likely to differ between both species, which would be attributed to species characteristics and/or differences in environmental conditions. In order to better understand the fine root dynamics of the $A$. alba and $R$. apiculata stands, future studies must simultaneously investigate fine root decomposition and elucidate the effects of belowground conditions, such as inundation periods and salinity.

\section{Acknowledgments}

We are grateful to Dr. Yoshimi Fujioka of the National Research Institute of Aquaculture, Fisheries Research Agency, and students of the Department of Botany, Faculty of Science, Chulalongkorn University for their kind assistance in field sampling and laboratory work in this study. We also extend our appreciation to the staff of the Andaman Coastal Development Research Station of Kasetsart University for their overall support of our fieldwork. This study was funded in part by the 
Global Environmental Research Account for National Institutes, Ministry of the Environment, Japan.

\section{References}

Adame, M. F. et al. (2014) Root Biomass and Production of Mangroves Surrounding a Karstic Oligotrophic Coastal Lagoon. Wetlands, 34, 479-488.

Alongi, D. M. (2012) Carbon sequestration in mangrove forests. Carbon Manage., 3, 313-322.

Brunner, I. \& Godbold, D. L. (2007) Tree roots in a changing world. J. For. Res., 12, 78-82.

Brunner, I. et al. (2013) Fine-root turnover rates of European forests revisited: an analysis of data from sequential coring and ingrowth cores. Plant Soil, 362, 357-372.

Cahoon, D. R. et al. (2003) Mass tree mortality leads to mangrove peat collapse at Bay Islands, Honduras after Hurricane Mitch. J. Ecol., 91, 1093-1105.

Castañeda-Moya, E. et al. (2011) Patterns of Root Dynamics in Mangrove Forests Along Environmental Gradients in the Florida Coastal Everglades, USA. Ecosystems, 14, 1178-1195.

Chalermchatwilai, B. et al. (2011) Distribution of fine-root necromass in a secondary mangrove forest in Trat province, Eastern Thailand. Science Asia, 37, 1-5.

Cormier, N. et al. (2015) Fine root productivity varies along nitrogen and phosphorus gradients in high-rainfall mangrove forests of Micronesia. Hydrobiologia, 750, 69-87.

Dahdouh-Guebas, F. et al. (2004) Comparative study of the disjunct zonation pattern of the grey mangrove Avicennia marina (Forsk.) Vierh. in Gazi Bay (Kenya). Bull. Marine Sci., 74, 237-252.

Donato, D. C. et al. (2011) Mangroves among the most carbonrich forests in the tropics. Nat. Geosci., 4, 293-297.

Finér, L. et al. (2011) Factors causing variation in fine root biomass in forest ecosystems. For. Ecol. Manage., 261, 265-277.

Fujimoto, K. (2004) Belowground carbon sequestration of mangrove forests in the Asia-Pacific region. In Mangrove management \& conservation: present and future, ed. Vannucci, M., United Nations University Press, Tokyo, Japan, pp. 138-146.

Fujimoto, K. et al. (1999) Mangrove habitat dynamics and Holocene sea-level changes in the southwestern coast of Thailand. Tropics, 8, 239-255.

Gill, A. M. \& Tomlinson, P. B. (1977) Studies on the growth of red mangrove (Rhizophora mangle L.) 4. The adult root system. Biotropica, 9, 145-155.

Gill, R. A. \& Jackson, R. B. (2000) Global patterns of root turnover for terrestrial ecosystems. New Phytol., 147, 13-31.

Gleason, S. M. \& Ewel, K. C. (2002) Organic matter dynamics on the forest floor of a Micronesian mangrove forest: An investigation of species composition shifts. Biotropica, 34, 190-198.

Hendrick, R. L. \& Pregitzer, K. S. (1993) The dynamics of fine root length, biomass, and nitrogen content in two northern hardwood ecosystems. Can. J. For. Res., 23, 2507-2520.

Hendrick, R. L. \& Pregitzer, K. S. (1996) Temporal and depthrelated patterns of fine root dynamics in northern hardwood forests. J. Ecol., 84, 167-176.

Hirata, Y. et al. (2010) Estimation of aboveground biomass in mangrove forest damaged by the major Tsunami disaster in 2004 in Thailand using high resolution satellite data. Int. Arch. Photogramm. Remote Sens. Spat. Inf. Sci., XXXVIII, Part 8, 643-646.

Komiyama, A. et al. (1988) Primary productivity of mangrove forest. In Biological System of Mangroves. A Report of East Indonesian Mangrove Expedition 1986, eds. Ogino, K. \& Chihara, M., Ehime University, Matsuyama, Japan, pp. 97-117.

Komiyama, A. et al. (1987) Root biomass of a mangrove forest in southern Thailand. 1. Estimation by the trench method and the zonal structure of root biomass. J. Trop. Ecol., 3, 97-108.

Komiyama, A. et al. (2008) Allometry, biomass, and productivity of mangrove forests: A review. Aquat. Bot., 89, 128-137.

Konôpka, B. et al. (2006) Fine root dynamics in a Japanese cedar (Cryptomeria japonica) plantation throughout the growing season. For. Ecol. Manage., 225, 278-286.

Makkonen, K. \& Helmisaari, H.-S. (1998) Seasonal and yearly variations of fine-root biomass and necromass in a Scots pine (Pinus sylvestris L.) stand. For. Ecol. Manage., 102, 283-290.

Matsumoto, Y. et al. (2006) Tsunami damage on the coastal vegetation along the west coast of Malay Peninsula from Krabi to Ranong, southern Thailand - Impacts of Tsunami at Andaman Ocean occurred in December 26, 2004. Jpn. J. For. Environ., 48, 43-56.

Mochida, Y. et al. (1999) A phytosociological study of the mangrove vegetation in the Malay Peninsula-Special reference to the micro-topography and mangrove depositTropics, 8, 207-220.

Noguchi, K. et al. (2007) Biomass and production of fine roots in Japanese forests. J. For. Res., 12, 83-95.

Ono, K. et al. (2015) Assessing the carbon compositions and sources of mangrove peat in a tropical mangrove forest on Pohnpei Island, Federated States of Micronesia. Geoderma, 245, 11-20.

Osawa, A. \& Aizawa, R. (2012) A new approach to estimate fine root production, mortality, and decomposition using litter bag experiments and soil core techniques. Plant Soil, 335, 167-181.

Parida. A. K. \& Jha, B. (2010) Salt tolerance mechanisms in mangroves: a review. Trees, 24, 199-217.

Persson, H. (1980) Spatial distribution of fine-root growth, mortality and decomposition in a young Scots pine stand in Central Sweden. Oikos, 34, 77-87

Poungparn, S. et al. (2016) Fine root production in three zones of secondary mangrove forest in eastern Thailand. Trees, 30, 467-474.

Rewald, B. et al. (2011) A root is a root is a root? Water uptake rates of Citrus root orders. Plant, Cell Environ., 34, 33-42.

Robertson \& Alongi (2016) Massive turnover rates of fine root detrital carbon in tropical Australian mangroves. Oecologia, 180, 841-851.

Srikanth, S. et al. (2016) Mangrove root: adaptations and ecological importance. Trees, 30, 451-465.

Strand, A. E. et al. (2008) Irreconcilable differences: Fine-root life spans and soil carbon persistence. Science, 319, 456-458. 
Tabuchi, R. (1995) Fine-root amount of young mangrove stands in Trang Province, Thailand. In Vegetation Science in Forestry, eds. Box, E. O. et al., Kluwer Academic Publishers, Netherlands, pp. 573-583.

Tabuchi, R. et al. (1983) Fine root amount of mangrove forest: A preliminary survey. Ind. J. Plant Sci., 1, 31-40.

Tateno, R. et al. (2004) Above- and belowground biomass and net primary production in a cool-temperate deciduous forest in relation to topographical changes in soil nitrogen. For. Ecol. Manage., 193, 297-306.
Volder, A. et al. (2005) Rapid decline in nitrate uptake and respiration with age in fine lateral roots of grape: implications for root efficiency and competitive effectiveness. New Phytol., 165, 493-502.

Wells, C. E. \& Eissenstat, D. M. (2001) Marked differences in survivorship among apple roots of different diameters. Ecology, 82, 882-892.

Xiong, Y. et al. (2017) Fine root functional group based estimates of fine root production and turnover rate in natural mangrove forests. Plant Soil, 413, 83-95.

Table S1. Fine root biomass in mangrove forests

\begin{tabular}{|c|c|c|c|c|c|c|c|}
\hline Study site & $\begin{array}{l}\text { Dominant species } \\
\text { (forest type) }\end{array}$ & $\begin{array}{c}\text { Depth } \\
\mathrm{cm}\end{array}$ & $\begin{array}{l}\text { Biomass } \\
\mathrm{kg} \mathrm{m}^{-2}\end{array}$ & $\begin{array}{l}\text { Necromass } \\
\mathrm{kg} \mathrm{m}^{-2}\end{array}$ & Sampling & $\begin{array}{l}\text { Live/Dead } \\
\text { separation }\end{array}$ & Reference \\
\hline $\begin{array}{l}\text { Southern Thailand } \\
\text { (Ranong) }\end{array}$ & Avicennia & $0-40$ & 3.38 & - & Soil coring & Firmness & This study \\
\hline $\begin{array}{l}\text { Southern Thailand } \\
\text { (Ranong) }\end{array}$ & Rhizophora & $0-40$ & 1.42 & - & Soil coring & Firmness & This study \\
\hline $\begin{array}{l}\text { Southern Thailand } \\
\text { (Trang) }\end{array}$ & $\begin{array}{l}\text { Rhizophora } \\
\text { (plantation, } 7 \text { years) }\end{array}$ & $0-100$ & 0.578 & - & Soil coring & - & Tabuchi (1995) \\
\hline $\begin{array}{l}\text { Southern Thailand } \\
\text { (Trang) }\end{array}$ & $\begin{array}{l}\text { Rhizophora } \\
\text { (plantation, } 10 \text { years) }\end{array}$ & $0-100$ & 0.386 & - & Soil coring & - & Tabuchi (1995) \\
\hline $\begin{array}{l}\text { Southern Thailand } \\
\text { (Trang) }\end{array}$ & $\begin{array}{l}\text { Rhizophora } \\
\text { (plantation, } 15 \text { years) }\end{array}$ & $0-100$ & 0.227 & - & Soil coring & - & Tabuchi (1995) \\
\hline $\begin{array}{l}\text { Southern Thailand } \\
\text { (Trang) }\end{array}$ & $\begin{array}{l}\text { Rhizophora } \\
\text { (plantation, } 20 \text { years) }\end{array}$ & $0-100$ & 0.209 & - & Soil coring & - & Tabuchi (1995) \\
\hline $\begin{array}{l}\text { Southern Thailand } \\
\text { (Trang) }\end{array}$ & $\begin{array}{l}\text { Rhizophora } \\
\text { (natural) }\end{array}$ & $0-100$ & 0.299 & - & Soil coring & - & Tabuchi (1995) \\
\hline $\begin{array}{l}\text { Southern Thailand } \\
\text { (Trang) }\end{array}$ & $\begin{array}{l}\text { Rhizophora } \\
\text { (natural) }\end{array}$ & $0-100$ & 0.238 & - & Soil coring & - & Tabuchi (1995) \\
\hline $\begin{array}{l}\text { Southern Thailand } \\
\text { (Trang) }\end{array}$ & $\begin{array}{l}\text { Rhizophora } \\
\text { (natural) }\end{array}$ & $0-100$ & 0.140 & - & Soil coring & - & Tabuchi (1995) \\
\hline $\begin{array}{l}\text { Southern Thailand } \\
\text { (Trang) }\end{array}$ & $\begin{array}{l}\text { Rhizophora } \\
\text { (natural) }\end{array}$ & $0-100$ & 0.183 & - & Soil coring & - & Tabuchi (1995) \\
\hline $\begin{array}{l}\text { Southern Thailand } \\
\text { (Trang) }\end{array}$ & $\begin{array}{l}\text { Rhizophora } \\
\text { (natural, gap) }\end{array}$ & $0-100$ & 0.672 & - & Soil coring & - & Tabuchi (1995) \\
\hline $\begin{array}{l}\text { Eastern Thailand } \\
\text { (Trat) }\end{array}$ & Avicennia-Sonneratia & $0-30$ & 0.089 & 0.994 & Soil coring & Color and firmness & $\begin{array}{c}\text { Chalermachatwilai } \\
\text { (2011) }\end{array}$ \\
\hline $\begin{array}{l}\text { Eastern Thailand } \\
\text { (Trat) }\end{array}$ & Rhizophora & $0-30$ & 0.075 & 2.11 & Soil coring & Color and firmness & $\begin{array}{l}\text { Chalermachatwilai } \\
\text { (2011) }\end{array}$ \\
\hline $\begin{array}{l}\text { Eastern Thailand } \\
\text { (Trat) }\end{array}$ & Xylocarpus & $0-30$ & 0.137 & 9.00 & Soil coring & Color and firmness & $\begin{array}{c}\text { Chalermachatwilai } \\
\text { (2011) }\end{array}$ \\
\hline $\begin{array}{l}\text { Southern China } \\
\text { (Hainan Island) }\end{array}$ & $\begin{array}{l}\text { Ceriops } \\
\text { (riverine) }\end{array}$ & $0-100$ & 1.9 & 2.1 & Soil coring & $\begin{array}{c}\text { Density } \\
\text { (colloidal silica) }\end{array}$ & Xiong et al. (2017) \\
\hline $\begin{array}{l}\text { Southern China } \\
\text { (Hainan Island) }\end{array}$ & $\begin{array}{l}\text { Ceriops } \\
\text { (seashore) }\end{array}$ & $0-100$ & 1.3 & 1.2 & Soil coring & $\begin{array}{c}\text { Density } \\
\text { (colloidal silica) }\end{array}$ & Xiong et al. (2017) \\
\hline $\begin{array}{l}\text { Southern China } \\
\text { (Hainan Island) }\end{array}$ & Bruguiera & $0-100$ & 0.61 & 1.8 & Soil coring & $\begin{array}{c}\text { Density } \\
\text { (colloidal silica) }\end{array}$ & Xiong et al. (2017) \\
\hline $\begin{array}{l}\text { Southern China } \\
\text { (Hainan Island) }\end{array}$ & Rhizophora & $0-100$ & 0.37 & 1.0 & Soil coring & $\begin{array}{c}\text { Density } \\
\text { (colloidal silica) }\end{array}$ & Xiong et al. (2017) \\
\hline $\begin{array}{l}\text { Southern China } \\
\text { (Hainan Island) }\end{array}$ & Avicennia & $0-100$ & 0.24 & 0.4 & Soil coring & $\begin{array}{c}\text { Density } \\
\text { (colloidal silica) }\end{array}$ & Xiong et al. (2017) \\
\hline $\begin{array}{l}\text { Micronesia } \\
\text { (Kosrae) }\end{array}$ & Bruguiera & $0-30$ & 0.72 & 13.1 & Soil coring & $\begin{array}{c}\text { Density } \\
\text { (colloidal silica) }\end{array}$ & $\begin{array}{c}\text { Gleason and Ewel } \\
\text { (2002) }\end{array}$ \\
\hline $\begin{array}{l}\text { Micronesia } \\
\text { (Kosrae) }\end{array}$ & Rhizophora & $0-30$ & 0.54 & 9.84 & Soil coring & $\begin{array}{c}\text { Density } \\
\text { (colloidal silica) }\end{array}$ & $\begin{array}{c}\text { Gleason and Ewel } \\
\text { (2002) }\end{array}$ \\
\hline
\end{tabular}


Table S1 (Continued).

\begin{tabular}{|c|c|c|c|c|c|c|c|}
\hline Study site & $\begin{array}{l}\text { Dominant species } \\
\text { (forest type) }\end{array}$ & $\begin{array}{l}\text { Depth } \\
\mathrm{cm}\end{array}$ & $\begin{array}{l}\text { Biomass } \\
\mathrm{kg} \mathrm{m}^{-2}\end{array}$ & $\begin{array}{l}\text { Necromass } \\
\mathrm{kg} \mathrm{m}^{-2}\end{array}$ & Sampling & $\begin{array}{l}\text { Live/Dead } \\
\text { separation }\end{array}$ & Reference \\
\hline $\begin{array}{l}\text { Micronesia } \\
\text { (Kosrae) }\end{array}$ & Sonneratia & $0-30$ & 0.78 & 13.2 & Soil coring & $\begin{array}{c}\text { Density } \\
\text { (colloidal silica) }\end{array}$ & $\begin{array}{c}\text { Gleason and Ewel } \\
\text { (2002) }\end{array}$ \\
\hline $\begin{array}{l}\text { Micronesia } \\
\text { (Kosrae) }\end{array}$ & $\begin{array}{l}\text { Bruguiera, Rhizophora, } \\
\text { Sonneratia (fringe) }\end{array}$ & $0-45$ & 0.151 & - & Soil coring & $\begin{array}{c}\text { Density } \\
\text { (colloidal silica) }\end{array}$ & $\begin{array}{l}\text { Cormier et al. } \\
\text { (2015) }\end{array}$ \\
\hline $\begin{array}{l}\text { Micronesia } \\
\text { (Kosrae) }\end{array}$ & $\begin{array}{l}\text { Bruguiera, Rhizophora, } \\
\text { Sonneratia (inland) }\end{array}$ & $0-45$ & 0.185 & - & Soil coring & $\begin{array}{c}\text { Density } \\
\text { (colloidal silica) }\end{array}$ & $\begin{array}{l}\text { Cormier et al. } \\
\qquad(2015)\end{array}$ \\
\hline $\begin{array}{l}\text { Micronesia } \\
\text { (Kosrae) }\end{array}$ & $\begin{array}{l}\text { Bruguiera, Rhizophora, } \\
\text { Sonneratia (riverine) }\end{array}$ & $0-45$ & 0.183 & - & Soil coring & $\begin{array}{c}\text { Density } \\
\text { (colloidal silica) }\end{array}$ & $\begin{array}{l}\text { Cormier et al. } \\
\text { (2015) }\end{array}$ \\
\hline $\begin{array}{l}\text { Micronesia } \\
\text { (Pohnpei) }\end{array}$ & $\begin{array}{l}\text { Bruguiera, Rhizophora, } \\
\text { Sonneratia etc. (fringe) }\end{array}$ & $0-45$ & 0.292 & - & Soil coring & $\begin{array}{c}\text { Density } \\
\text { (colloidal silica) }\end{array}$ & $\begin{array}{l}\text { Cormier et al. } \\
\text { (2015) }\end{array}$ \\
\hline $\begin{array}{l}\text { Micronesia } \\
\text { (Pohnpei) }\end{array}$ & $\begin{array}{l}\text { Bruguiera, Rhizophora, } \\
\text { Sonneratia etc. (inland) }\end{array}$ & $0-45$ & 0.577 & - & Soil coring & $\begin{array}{c}\text { Density } \\
\text { (colloidal silica) }\end{array}$ & $\begin{array}{l}\text { Cormier et al. } \\
\text { (2015) }\end{array}$ \\
\hline $\begin{array}{l}\text { Micronesia } \\
\text { (Pohnpei) }\end{array}$ & $\begin{array}{l}\text { Bruguiera, Rhizophora, } \\
\text { Sonneratia etc. } \\
\text { (riverine) }\end{array}$ & $0-45$ & 0.170 & - & Soil coring & $\begin{array}{c}\text { Density } \\
\text { (colloidal silica) }\end{array}$ & $\begin{array}{l}\text { Cormier et al. } \\
\qquad(2015)\end{array}$ \\
\hline $\begin{array}{l}\text { North-eastern } \\
\text { Australia } \\
\text { (Hinchinbrook } \\
\text { Island) }\end{array}$ & Rhizophora & $0-100$ & 0.8 & 16.3 & Soil coring & $\begin{array}{c}\text { Density } \\
\text { (colloidal silica) }\end{array}$ & $\begin{array}{l}\text { Robertson and } \\
\text { Alongi (2016) }\end{array}$ \\
\hline $\begin{array}{l}\text { North-eastern } \\
\text { Australia } \\
\text { (Hinchinbrook } \\
\text { Island) }\end{array}$ & Rhizophora & $0-100$ & 1.1 & 28.4 & Soil coring & $\begin{array}{c}\text { Density } \\
\text { (colloidal silica) }\end{array}$ & $\begin{array}{l}\text { Robertson and } \\
\text { Alongi (2016) }\end{array}$ \\
\hline $\begin{array}{l}\text { North-eastern } \\
\text { Australia } \\
\text { (Hinchinbrook } \\
\text { Island) }\end{array}$ & Ceriops & $0-100$ & 0.9 & 8.9 & Soil coring & $\begin{array}{c}\text { Density } \\
\text { (colloidal silica) }\end{array}$ & $\begin{array}{l}\text { Robertson and } \\
\text { Alongi (2016) }\end{array}$ \\
\hline $\begin{array}{l}\text { Florida, USA } \\
\text { (SRS-4) }\end{array}$ & $\begin{array}{l}\text { Rhizophora, } \\
\text { Laguncularia, } \\
\text { Conocurpus (riverine) }\end{array}$ & $0-90$ & 0.587 & - & Soil coring & $\begin{array}{c}\text { Density } \\
\text { (fresh water) }\end{array}$ & $\begin{array}{l}\text { Castañeda-Moya } \\
\text { et al. (2011) }\end{array}$ \\
\hline $\begin{array}{l}\text { Florida, USA } \\
\text { (SRS-5) }\end{array}$ & $\begin{array}{l}\text { Rhizophora, } \\
\text { Laguncularia, } \\
\text { Avicennia (riverine) }\end{array}$ & $0-90$ & 0.442 & - & Soil coring & $\begin{array}{c}\text { Density } \\
\text { (fresh water) }\end{array}$ & $\begin{array}{l}\text { Castañeda-Moya } \\
\text { et al. (2011) }\end{array}$ \\
\hline $\begin{array}{l}\text { Florida, USA } \\
\text { (SRS-6) }\end{array}$ & $\begin{array}{l}\text { Rhizophora, } \\
\text { Laguncularia, } \\
\text { Avicennia (riverine) }\end{array}$ & $0-90$ & 0.353 & - & Soil coring & $\begin{array}{c}\text { Density } \\
\text { (fresh water) }\end{array}$ & $\begin{array}{l}\text { Castañeda-Moya } \\
\text { et al. (2011) }\end{array}$ \\
\hline $\begin{array}{l}\text { Florida, USA } \\
\text { (TS/Ph-6) }\end{array}$ & Rhizophora (scrub) & $0-90$ & 0.324 & - & Soil coring & $\begin{array}{c}\text { Density } \\
\text { (fresh water) }\end{array}$ & $\begin{array}{l}\text { Castañeda-Moya } \\
\text { et al. (2011) }\end{array}$ \\
\hline $\begin{array}{l}\text { Florida, USA } \\
(\mathrm{TS} / \mathrm{Ph}-7)\end{array}$ & Rhizophora (scrub) & $0-90$ & 0.508 & - & Soil coring & $\begin{array}{c}\text { Density } \\
\text { (fresh water) }\end{array}$ & $\begin{array}{l}\text { Castañeda-Moya } \\
\text { et al. (2011) }\end{array}$ \\
\hline $\begin{array}{l}\text { Florida, USA } \\
\text { (TS/Ph-8) }\end{array}$ & $\begin{array}{l}\text { Rhizophora, } \\
\text { Conocurpus (fringe) }\end{array}$ & $0-90$ & 0.661 & - & Soil coring & $\begin{array}{c}\text { Density } \\
\text { (fresh water) }\end{array}$ & $\begin{array}{l}\text { Castañeda-Moya } \\
\text { et al. (2011) }\end{array}$ \\
\hline $\begin{array}{l}\text { Eastern Indonesia } \\
\text { (Halmahera } \\
\text { Island) }\end{array}$ & Rhizophora & $0-100$ & 0.64 & - & $\begin{array}{l}\text { Soil block } \\
\text { sampling }\end{array}$ & - & $\begin{array}{c}\text { Komiyama et al. } \\
\text { (1988) }\end{array}$ \\
\hline $\begin{array}{l}\text { Eastern Indonesia } \\
\text { (Halmahera } \\
\text { Island) }\end{array}$ & Bruguiera & $0-100$ & 0.66 & - & $\begin{array}{l}\text { Soil block } \\
\text { sampling }\end{array}$ & - & $\begin{array}{c}\text { Komiyama et al. } \\
\text { (1988) }\end{array}$ \\
\hline $\begin{array}{l}\text { Eastern Indonesia } \\
\text { (Halmahera } \\
\text { Island) }\end{array}$ & Sonneratia & $0-100$ & 0.49 & - & $\begin{array}{l}\text { Soil block } \\
\text { sampling }\end{array}$ & - & $\begin{array}{c}\text { Komiyama et al. } \\
\text { (1988) }\end{array}$ \\
\hline $\begin{array}{l}\text { Southern Thailand } \\
\text { (Ranong) }\end{array}$ & Rhizophora & $0-100$ & 22.1 & - & $\begin{array}{l}\text { Soil block } \\
\text { sampling } \\
\text { (trench) }\end{array}$ & Color and firmness & $\begin{array}{l}\text { Komiyama et al. } \\
\text { (1987) }\end{array}$ \\
\hline
\end{tabular}


Table S2. Fine root production rates in mangrove forests estimated by the ingrowth core method

\begin{tabular}{|c|c|c|c|c|c|}
\hline Study site & Dominant species (forest type) & $\begin{array}{l}\text { Soil depth } \\
\text { (cm) }\end{array}$ & $\begin{array}{c}\text { FRP } \\
\mathrm{g} \mathrm{m}^{-2} \mathrm{y}^{-1}\end{array}$ & $\begin{array}{l}\text { Live/Dead status of } \\
\text { fine roots examined }\end{array}$ & Reference \\
\hline $\begin{array}{l}\text { Southern Thailand } \\
\text { (Ranong) }\end{array}$ & Avicennia & $0-40$ & 451 & Live + Dead & This study \\
\hline $\begin{array}{l}\text { Southern Thailand } \\
\text { (Ranong) }\end{array}$ & Rhizophora & $0-40$ & 736 & Live + Dead & This study \\
\hline $\begin{array}{l}\text { Eastern Thailand } \\
\text { (Trat) }\end{array}$ & Avicennia-Sonneratia & $0-30$ & 332 & Live + Dead & Poungparn et al. (2016) \\
\hline $\begin{array}{l}\text { Eastern Thailand } \\
\text { (Trat) }\end{array}$ & Rhizophora & $0-30$ & 1,340 & Live + Dead & Poungparn et al. (2016) \\
\hline $\begin{array}{l}\text { Eastern Thailand } \\
\text { (Trat) }\end{array}$ & Xylocarpus & $0-30$ & 1,010 & Live + Dead & Poungparn et al. (2016) \\
\hline Micronesia (Kosrae) & $\begin{array}{l}\text { Bruguiera, Rhizophora, } \\
\text { Sonneratia (fringe) }\end{array}$ & $0-45$ & 45.9 & Live & Cormier et al. (2015) \\
\hline Micronesia (Kosrae) & $\begin{array}{l}\text { Bruguiera, Rhizophora, } \\
\text { Sonneratia (inland) }\end{array}$ & $0-45$ & 91.0 & Live & Cormier et al. (2015) \\
\hline Micronesia (Kosrae) & $\begin{array}{l}\text { Bruguiera, Rhizophora, } \\
\text { Sonneratia (riverine) }\end{array}$ & $0-45$ & 100 & Live & Cormier et al. (2015) \\
\hline Micronesia (Pohnpei) & $\begin{array}{l}\text { Bruguiera, Rhizophora, } \\
\text { Sonneratia etc. (fringe) }\end{array}$ & $0-45$ & 63.2 & Live & Cormier et al. (2015) \\
\hline Micronesia (Pohnpei) & $\begin{array}{l}\text { Bruguiera, Rhizophora, } \\
\text { Sonneratia etc. (inland) }\end{array}$ & $0-45$ & 119 & Live & Cormier et al. (2015) \\
\hline Micronesia (Pohnpei) & $\begin{array}{l}\text { Bruguiera, Rhizophora, } \\
\text { Sonneratia etc. (riverine) }\end{array}$ & $0-45$ & 95.2 & Live & Cormier et al. (2015) \\
\hline Micronesia (Kosrae) & Bruguiera & $0-15$ & 49.5 & - & $\begin{array}{l}\text { Gleason and Ewel } \\
\text { (2002) }\end{array}$ \\
\hline Micronesia (Kosrae) & Rhizophora & $0-15$ & 43.5 & - & $\begin{array}{l}\text { Gleason and Ewel } \\
\text { (2002) }\end{array}$ \\
\hline Micronesia (Kosrae) & Sonneratia & $0-15$ & 417 & - & $\begin{array}{l}\text { Gleason and Ewel } \\
\text { (2002) }\end{array}$ \\
\hline $\begin{array}{l}\text { Florida, USA (SRS- } \\
\text { 4) }\end{array}$ & $\begin{array}{l}\text { Rhizophora, Laguncularia, } \\
\text { Conocurpus (riverine) }\end{array}$ & $0-90$ & 206 & Live & $\begin{array}{c}\text { Castañeda-Moya et al. } \\
\text { (2011) }\end{array}$ \\
\hline $\begin{array}{l}\text { Florida, USA (SRS- } \\
\text { 5) }\end{array}$ & $\begin{array}{l}\text { Rhizophora, Laguncularia, } \\
\text { Avicennia (riverine) }\end{array}$ & $0-90$ & 210 & Live & $\begin{array}{c}\text { Castañeda-Moya et al. } \\
\text { (2011) }\end{array}$ \\
\hline $\begin{array}{l}\text { Florida, USA (SRS- } \\
6 \text { ) }\end{array}$ & $\begin{array}{l}\text { Rhizophora, Laguncularia, } \\
\text { Avicennia (riverine) }\end{array}$ & $0-90$ & 183 & Live & $\begin{array}{c}\text { Castañeda-Moya et al. } \\
\text { (2011) }\end{array}$ \\
\hline $\begin{array}{l}\text { Florida, USA (TS/ } \\
\text { Ph-6) }\end{array}$ & Rhizophora (scrub) & $0-90$ & 137 & Live & $\begin{array}{c}\text { Castañeda-Moya et al. } \\
\text { (2011) }\end{array}$ \\
\hline $\begin{array}{l}\text { Florida, USA (TS/ } \\
\text { Ph-7) }\end{array}$ & Rhizophora (scrub) & $0-90$ & 130 & Live & $\begin{array}{c}\text { Castañeda-Moya et al. } \\
\text { (2011) }\end{array}$ \\
\hline $\begin{array}{l}\text { Florida, USA (TS/ } \\
\text { Ph-8) }\end{array}$ & $\begin{array}{l}\text { Rhizophora, Conocurpus } \\
\text { (fringe) }\end{array}$ & $0-90$ & 164 & Live & $\begin{array}{c}\text { Castañeda-Moya et al. } \\
\text { (2011) }\end{array}$ \\
\hline $\begin{array}{l}\text { Honduras (Roatan } \\
\text { Island) }\end{array}$ & Rhizophora (fringe) & $0-30$ & 233 & - & Cahoon et al. (2003) \\
\hline $\begin{array}{l}\text { Honduras (Roatan } \\
\text { Island) }\end{array}$ & Rhizophora, Avicennia (basin) & $0-30$ & 206 & - & Cahoon et al. (2003) \\
\hline $\begin{array}{l}\text { Honduras (Roatan } \\
\text { Island) }\end{array}$ & $\begin{array}{l}\text { Rhizophora (fringe, hurricane } \\
\text { impacted) }\end{array}$ & $0-30$ & 164 & - & Cahoon et al. (2003) \\
\hline $\begin{array}{l}\text { Honduras (Roatan } \\
\text { Island) }\end{array}$ & $\begin{array}{l}\text { Rhizophora, Avicennia (basin, } \\
\text { hurricane impacted) }\end{array}$ & $0-30$ & 136 & - & Cahoon et al. (2003) \\
\hline
\end{tabular}


Table S3.Root mass in individual ingrowth core samples in the Avicennia alba stand

\begin{tabular}{cccc}
\hline \hline $\begin{array}{c}\text { Soil depth } \\
(\mathrm{cm})\end{array}$ & $\begin{array}{c}\text { Sampling } \\
\text { location }\end{array}$ & $\begin{array}{c}\text { Dry weight of roots } \\
<2 \mathrm{~mm} \text { in diameter } \\
\left(\mathrm{g} \mathrm{core}^{-1}\right)\end{array}$ & $\begin{array}{c}\text { Dry weight of roots } \\
2 \mathrm{~mm}-5 \mathrm{~mm} \text { in diameter } \\
\left(\mathrm{g} \mathrm{core}^{-1}\right)\end{array}$ \\
\hline $0-20$ & A1 & 0.1831 & 0 \\
$0-20$ & A2 & 0.5589 & 0.0081 \\
$0-20$ & A3 & 0.3974 & 0 \\
$0-20$ & A4 & 0.1536 & 0.0628 \\
$0-20$ & A5 & 0.2013 & 0 \\
$0-20$ & A6 & 0.1126 & 0 \\
$20-40$ & A1 & 0.1338 & 0 \\
$20-40$ & A2 & 0.1106 & 0.0285 \\
$20-40$ & A3 & 0.1279 & 0 \\
$20-40$ & A4 & 0.0726 & 0 \\
$20-40$ & A5 & 0.0551 & 0 \\
$20-40$ & A6 & 0.0675 & 0 \\
\hline
\end{tabular}

Table S4.Root mass in individual ingrowth core samples in the Rhizophora apiculata stand

\begin{tabular}{cccc}
\hline \hline $\begin{array}{c}\text { Soil depth } \\
(\mathrm{cm})\end{array}$ & $\begin{array}{c}\text { Sampling } \\
\text { location }\end{array}$ & $\begin{array}{c}\text { Dry weight of roots } \\
<2 \text { mm in diameter } \\
\left(\mathrm{g} \mathrm{core}^{-1}\right)\end{array}$ & $\begin{array}{c}\text { Dry weight of roots } \\
\mathrm{mm}-5 \mathrm{~mm} \text { in diameter } \\
\left(\mathrm{g} \mathrm{core}^{-1}\right)\end{array}$ \\
\hline $0-20$ & R 1 & 0.1242 & 0.0258 \\
$0-20$ & R 2 & 0.1448 & 0 \\
$0-20$ & R 3 & 0.2866 & 0 \\
$0-20$ & R 4 & 0.3513 & 0 \\
$0-20$ & R 5 & 0.2501 & 0.0302 \\
$0-20$ & R 6 & 0.3523 & 0 \\
$0-20$ & R 7 & 0.1940 & 0 \\
$0-20$ & R 8 & 0.2087 & 0.0219 \\
$0-20$ & R 9 & 0.5423 & 0.1016 \\
$0-20$ & R10 & 0.3034 & 0.0142 \\
$20-40$ & R 1 & 0.3293 & 0.0110 \\
$20-40$ & R 2 & 0.2324 & 0 \\
$20-40$ & R 3 & 0.3633 & 0 \\
$20-40$ & R 4 & 0.2372 & 0.0180 \\
$20-40$ & R 5 & 0.3268 & 0.0559 \\
$20-40$ & R 6 & 0.3398 & 0 \\
$20-40$ & R 7 & 0.2578 & 0.2803 \\
$20-40$ & R 8 & 0.4929 & 0.0435 \\
$20-40$ & R 9 & 0.3718 & 0 \\
$20-40$ & R10 & 0.2089 & 0.0556 \\
\hline & & & \\
\hline
\end{tabular}


K. Noguchi et al.

Table S5.Fine root biomass in individual soil core samples in the Avicennia alba and Rhizophora apiculata stands

\begin{tabular}{lrcc}
\hline \hline Stand & $\begin{array}{c}\text { Soil depth } \\
(\mathrm{cm})\end{array}$ & $\begin{array}{c}\text { Sampling } \\
\text { location }\end{array}$ & $\begin{array}{c}\text { Dry weight of roots } \\
<2 \text { mm in diameter } \\
\left(\mathrm{g} \mathrm{core}^{-1}\right)\end{array}$ \\
\hline Avicennia & $0-20$ & AS1 & 1.4369 \\
Avicennia & $0-20$ & AS2 & 1.3034 \\
Avicennia & $0-20$ & AS3 & 1.8923 \\
Avicennia & $0-20$ & AS4 & 1.9524 \\
Avicennia & $0-20$ & AS5 & 0.9725 \\
Avicennia & $20-40$ & AS1 & 1.3034 \\
Avicennia & $20-40$ & AS2 & 1.8923 \\
Avicennia & $20-40$ & AS3 & 1.9524 \\
Avicennia & $20-40$ & AS4 & 0.9725 \\
Avicennia & $20-40$ & AS5 & 0.7255 \\
Rhizophora & $0-20$ & RS1 & 0.4674 \\
Rhizophora & $0-20$ & RS2 & 0.6422 \\
Rhizophora & $0-20$ & RS3 & 0.8234 \\
Rhizophora & $0-20$ & RS4 & 1.335 \\
Rhizophora & $0-20$ & RS5 & 0.3259 \\
Rhizophora & $20-40$ & RS1 & 0.6422 \\
Rhizophora & $20-40$ & RS2 & 0.8234 \\
Rhizophora & $20-40$ & RS3 & 1.335 \\
Rhizophora & $20-40$ & RS4 & 0.3259 \\
Rhizophora & $20-40$ & RS5 & 0.6642 \\
\hline
\end{tabular}

